\title{
EFEKTIVITAS MODEL PEMBELAJARAN NUMBERED HEAD TOGETHER DAN THINK PAIR SHARE DITINJAU DARI KETERAMPILAN BERKOMUNIKASI SISWA SD
}

\author{
Zefania Putri Zefacha \\ Universitas Kristen Satyawacana \\ J1. Diponegoro No.52-60 \\ Email: 292016113@stundent.uksw.edu \\ Mawardi \\ Universitas Kristen Satyawacana \\ J1. Diponegoro No.52-60 \\ Email: mawardi@staff.uksw.edu
}

\begin{abstract}
This research aims to determine whether the Numbered Head Together learning model is more effective than the Think Pair Share model in terms of communication skills in elementary students. This research uses an experimental research type Quasi Experiment with Post Test-Only Control Group Design. The population of the research is the 5th grade students of the Diponegoro Cluster Salatiga City, with a total of 164 students, the sample taken was 111 students. This research instrument uses an integrated communication skills rubric with an assignment report in the form of a Mind Map. Data analysis techniques using descriptive techniques and statistical techniques Mann Whitney test. The research results showed that in Experiment group 1 with the number of students $(\mathrm{N})$ as many as 56 students reached the average value of the level of communication skills of 90.52 . Whereas in Experiment 2 the number of students $(\mathrm{N})$ is 55 students reached an average of 79.82. the results of communication skills in the experimental group 1 were higher strengthened by the results of the Mann Whitney test. Based on the Mann Whitney test obtained the results of $\mathrm{U}$ value is 905.000 and $\mathrm{W}$ value is 2445.000 . Which if converted to $\mathrm{Z}$ value has a result of -3.800 . Sig or $\mathrm{P}$ value is $000<0.05$ thus there is a significant difference between the two groups which means $\mathrm{H} 1$ is accepted. This means that communication skills using the Numbered Head Together model are significantly higher than communication skills using the Think Pair Share learning model.
\end{abstract}

\section{Keyword:}

Communication, Numbered Head Together, Think Pair Share

\begin{abstract}
Abstrak
Penelitian ini bertujuan untuk mengetahui apakah model pembelajaran Numbered Head Together lebih efektif daripada model Think Pair Share ditinjau dari keterampilan komunikasi pada siswa SD. Penelitian ini menggunakan penelitian eksperimen jenis Quasi Eksperimen dengan desain Post test-Only Control Group Design. Populasi penelitian yaitu siswa kelas 5 Gugus Diponegoro Kota Salatiga, dengan jumlah 164 siswa, sampel diambil sebesar 111 siswa. Instrumen penelitian ini menggunakan rubrik keterampilan komunikasi terintegrasi dengan laporan penugasan berupa Peta Pikir. Teknik analisis data menggunakan teknik deskriptif dan teknik statistik uji Mann Whitney. Hasil penelitian menunjukan bahwa pada kelompok Eksperimen 1 dengan jumlah siswa (N) sebanyak 56 siswa mencapai nilai rata-rata tingkat keterampilan berkomunikasi sebesar 90.52. Sedangkan pada Eksperimen 2 dengan jumlah siswa $(\mathrm{N})$ sebanyak 55 siswa mencapai rata-rata 79.82. Hasil keterampilan komunikasi pada kelompok eksperimen 1 lebih tinggi diperkuat dengan hasil uji Mann Whitney. Berdasarkan uji Mann Whitney diperoleh hasil nilai U sebesar 905.000 dan Nilai W sebesar 2445.000. Apa bila dikonversikan ke nilai Z maka memiliki hasil -3.800. Nilai Sig atau $\mathrm{P}$ value sebesar $000<0,05$ dengan demikian terdapat perbedaan bermakna antara kedua kelompok yang berarti $\mathrm{H}_{1}$ diterima. Artinya keterampilan komunikasi menggunakan model Numbered Head Together lebih tinggi secara signifikan dibandingkan dengan keterampilan komunikasi menggunakan model pembelajaran Think Pair Share.
\end{abstract}

Kata Kunci:

Berkomunikasi; Numbered Head Together; Think Pair Share

\section{A. PENDAHULUAN}

Dunia pendidikan saat ini khususnya untuk jenjang sekolah dasar menggunakan pembelajaran yang menggunakan kurikulum. Dalam kurikulum sudah menerapkan pembelajaran tematik. Pembelajaran tematik merupakan proses pembelajaran yang tersusun secara terpadu. Pembelajaran terpadu mengajarkan kepada siswa 
pembelajaran yang memiliki makna sehingga dapat diingat dan dipahami siswa. Pada proses pembelajaran yang diberikan oleh guru di SD disajikan secara terpadu (Kemendikbud, 2003). Pembelajaran tematik yang satu bagiannya yaitu tema yang dipakai untuk memadukan pembelajaran dengan beberapa mata pelajaran sekaligus dalam satu kali pertemuan, untuk menjadikan pengalaman yang bermakna bagi siswa (Permendikbud, 2004). Faisal dan Lova (2018:23) mengatakan bahwa pembelajaran bermakna dalam pembelajaran tematik siswa akan dapat memahami konsep-konsep yang mereka pelajari melalui pengalaman langsung dan nyata yang menghubungkan antar konsep dalam indra maupun antar mata pelajaran. Apabila pembelajaran bermakna dibandingkan dengan pembelajaran konvensional maka pembelajaran tematik akan terlihat lebih menekankan pada keterlibatan siswa dalam proses pembelajaran sehingga siswa terlibat dalam proses pembelajaran untuk pembuatan keputusan. Dengan pembelajaran tematik siswa dapat memperoleh pembelajaran yang bermakna, karena pembelajaran tematik integratik terdiri dari beberapa muatan pembelajaran yang disusun dan dipadukan menjadi satu kesatuan dalam tema. Dari beberapa pendapat mengenai pembelajaran tematik integratif dapat disimpulkan bahwa pembelajaran integratif merupakan pembelajaran yang bermakna yang didalamnya berisikan tentang berbagai muatan mata pelajaran yang padu dan berbentuk tema yang pembelajarannya dilakukan dalam tiap harinya.

Berdasarkan kaitannya dengan peran guru dalam proses pembelajaran, pada abad 21 dalam mengajar peserta didik diperlukan beberapa kompetensi dan keterampilan yang dapat diberikan untuk mengatasi tantangan global, seperti 4 keterampilan yang ada yaitu Communication, Collaboration, Critical Thinking and Problem Solving (Arifin, 2017:93). Salah satu dari kompetensi dan keterampilan yang sesuai dengan pembelajaran tematik yaitu komunikasi. Menurut pendapat Siti Zubaidah $(2016 ; 4)$ keterampilan komunikasi mencakup keterampilan dalam menyampaikan pemikiran dengan jelas dan persuasif secara langsung maupun tertulis, kemampuan menyampaikan opini secara jelas, menyampaikan perintah secara jelas, dan mampu memberikan motivasi kepada orang lain secara jelas. Dalam dunia modern dalam persaingan didunia industri keterampilan dalam berkomunikasi sangat dibutuhkan, oleh sebab itu didalam dunia pendidikan guru harus mengambangkan kompetensi dan keterampilan peserta didik dalam berkomunikasi secara baik.

Model pembelajaran yang mendukung keterampilan komunikasi dan sesuai dengan kurikulum k13 salah satunya adalah model pembelajaran Numbered Heads Together. Aliputri, Sulasmono dan Setyaningsih (2019;25) berpendapat bahwa Numbered Heads Together merupakan model pembelajaran yang dalam kegiatannya berisikan bahwa setiap siswa akan saling berbagi informasi, dan menjawab soal sesuai dengan nomor yang sudah dipanggil. Semua tim kelompok harus memahami dan mampu menyelesaikan pertanyaan yang diberikan oleh guru. Model pembelajaran yang kedua adalah Think Pair Share. Menurut Sari, Sesunan, dan Nyeneng (2019;69) mengatakan bahwa model pembelajaran Think Pair Share yaitu suatu cara yang digunakan dalam model pembelajaran yang dilakukan secara efektif untuk membuat suasana kelas menjadi beragam, pada model pembelajaran Think Pair Share siswa dituntut untuk berpartisipasi secara aktif dalam mengungkapkan ide dan gagasannya, dengan demikian secara langsung siswa diajarkan banyak berinteraksi dengan siswa lainnya. model pembelajaran think pair share menumbuhkan keberanian yang tinggi dalam menyampaikan ide dan gagasan yang sudah diperoleh dalam kelompok dan disampaikannya didepan kelas. langkah-langkah yang digunakan dalam model pembelajaran think pair share dapat memberikan banyak waktu kepada siswa untuk berpikir, merespon dan membantu sesama siswa lainnya. Model pembelajaran Think Pair Share merupakan proses pembelajaran yang dilakukan untuk bisa memberikan kesempatan kepada peserta didik untuk bisa membangun konsep, hukum dan prinsip dengan berfikir sendiri (Fajrin, Wardani, Prasetyo (2019, 36 - 37).

Model Pembelajaran Number Head Together dan Think Pair Share mempunyai persamaan dapat meningkatkan kemampuan berkomunikasi Peserta didik. Numbered Head Together menekankan kepada siswa untuk saling bekerja sama antar kelompok untuk berbagi informasi. Think Pair Share menekankan pada penemuan untuk siswa dibentuk kelas secara berpasangan 
dengan tahap berpikir bersama dengan waktu yang cukup lama, setelah itu berdiskusi dan membagikan informasi kepada pasangan yang lainnya. Berpijak dari hasil penelitian sebelumnya terhadap keefektifan penerapan model Numbered Head Together dan Think Pair Share pada muatan pelajaran sehingga menimbulkan keragu-raguan bagi peneliti.

Adapun penelitian-penelitian yang pernah dilakukan sebelumnya membuktikan bahwa model pembelajaran Numbered Head Together lebih efektif dibandingkan dengan model pembelajaran Think Pair Share antara lain Aliputri, Sulasmono dan Wiidyanti (2019:30) menyatakan bahwa model pembelajaran Numbered Head Together lebih efektif dari model pembelajaran Think pair share ditinjau dari hasil belajar matematika siswa kelas IV SDN Wulung 1 Kecamatan Randublatung Kabupaten Blora Semester II Tahun pelajaran 2018/2019. Fauziah (2019:9) menyatakan bahwa pembelajaran dengan menggunakan model pembelajaran Numbered Head Together memiliki banyak pengaruh untuk meningkatkan komunikasi siswa kelas VII SMP Negeri 3 Kartasura. Khusnaini (2011:108) menyatakan bahwa pembelajaran dengan menggunakan model Numbered Head Together lebih efektif dari model pembelajaran Think Pair Share dalam meningkatkan komunikasi siswa pada pembelajaran matematika. Rianingsih, Mawardi, Wardani (2019:344) menyatakan bahwa pembelajaran dengan menggunakan model pembelajaran TPS Think Pair Share dapat meningkatkan keterampilan komunikasi siswa kelas 3 SDN Ledok 05 salatiga. Rizkiana (2019:58) menyatakan bahwa model pembelajaran Think Pairs Share lebih efektif dari pembelajaran konvensional ditinjau dari kemampuan komunikasi matematis siswa. Daeka (2014: 89) mengatakan bahwa pembelajaran dengan menggunakan model pembelajaran Numbered Head Together dan Think Pair Share sama efektifnya, dan kedua model pembelajaran tersebut lebih unggul dibandingkan dengan model konvensional. Berdasarkan penelitian terdahulu mengenai efektivitas model pembelajaran Numbered Head Together dan Think Pair Share menimbulkan keragu-raguan kepada penulis mengenai model pembelajaran yang lebih baik dalam upaya peningkatan hasil belajar siswa kelas 5 SD.

Penelitian ini hendak membuktikan apakah model pembelajaran kooperatif tipe Numbered Head Together lebih unggul dari Think Pairs Share ditinjau dari berkomunikasi siswa. Dari berbagai model pembelajaran kooperatif, peneliti tertarik untuk meneliti keampuhan model pembelajaran Numbered Head Together lebih unggul dari Think Pairs Share, karena terdapat perbedaan hasil penelitian terdahulu yang menyatakan bahwa Numbered Head Together lebih efektif untuk meningkatkan komunikasi siswa dibanding model Think Pairs Share.

Dalam hal ini peneliti menggunakan jenis penelitian Quasi Eksperimen dengan Desain penelitian Post test-Only Control Group Design. Menurut pendapat L.R Gay(2012:268) mengatakan bahwa penelitian dengan desain Post test-Only Control Group merupakan penelitian yang dibagi menjadi dua kelompok yaitu kelompok eksperimen dan kelompok kontrol, desain Post Test-Only menjadi desain penelitian yang efektif untuk mencari desain yang terbaik. Dalam desain ini terdapat dua kelompok yang masing-masing dipilih secara random (R) yang kemudian masing-masing kelas diberi perlakuan yang sama (X),yaitu:

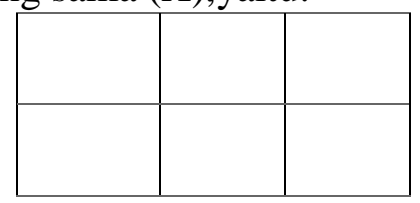

Keterangan:

$\mathrm{R}$ : Kelompok Random

$\mathrm{X}$ : Perlakuan yang diberikan

$\mathrm{O}$ : Nilai Tes Akhir

Populasi yang digunakan yaitu siswa kelas 5 Gugus Diponegoro yang terletak di wilayah Kec.Sidomukti, Kota Salatiga. Peneliti memilih sampel yang digunakan untuk peneliti berjumlah 164 siswa yang terdiri dari SDN Mangunsari 01(40 siswa), SDN Mangunsari 03 (30 siswa) dan SDN Mangunsari 05 (41 siswa), pada penelitian ini menggunakan rubrik instrumen keterampilan komunikasi yang diadopsi dari Siti Zubaidah terintegrasi dengan laporan penugasan berupa Peta Pikir. Dalam hal ini peneliti menggunakan teknik analisis data dengan cara presentasi berupa laporan penugasan siswa berupa peta pikir. Penelitian dilakukan dengan cara menentukan kelas eksperimen 1 dan Eksperimen 2, kelas 
eksperimen 1 menggunakan model Numbered Head Together kelas 2 sebagai Eksperimen 2 dengan menggunakan model Think Pairs Share. Dalam penilaian menggunakan instrumen komunikasi yang terdiri dari 6 aspek komunikasi untuk menilai keterampilan siswa dalam berkomunikasi. Penelitian dilakukan 2 hari penuh untuk satu sekolah setara dengan 1 pembelajaran, teknik pengumpulan data dengan melakukan penelitian di kelas untuk mengukur keterampilan komunikasi dengan presentasi.

\section{B. HASIL DAN PEMBAHASAN \\ 1. Hasil}

Hasil dari analisis penelitian dilakukan pada siswa kelas 5 Gugus diponegoro yang terletak di wilayah Kec.Sidomukti, Kota Salatiga semester II tahun pelajaran 2019/2020 dengan populasi dengan jumlah 164 siswa. Peneliti memilih sampel yang digunakan untuk peneliti berjumlah
111 siswa yang terdiri dari SDN Mangunsari 01(40 siswa), SDN Mangunsari 03 (30 siswa) dan SDN Mangunsari 05 (41 siswa), sebagai kelas eksperimen 1 dan Eksperimen 2. Pembagian kelasnya dilakukan secara random yaitu dengan membaginya menjadi 2 kelompok dalam satu kelasnya. Perlakuan yang diberikan kepada dua kelompok sampel dengan pembelajaran yang sama yaitu tentang "Peristiwa Dalam Kehidupan", dimana pelaksanaan pembelajaran yang berbeda yaitu kelas eksperimen yang menerima perlakuan dengan menggunakan model pembelajaran Numbered Head Together dan kelas kontrol yang menggunakan perlakuan dengan pembelajaran Think Pair Share.

Komparasi keterampilan komunikasi dari dua kelompok tersebut dapat dicermati dari tabel 1.

Tabel 1. Statistik Deskriptif

\begin{tabular}{|l|r|r|r|r|r|r|}
\hline \multicolumn{7}{|c|}{ Descriptive Statistics } \\
\cline { 2 - 7 } & Parameter & Minimum & Maximum & \multicolumn{2}{|c|}{ Mean } & $\begin{array}{c}\text { Std. } \\
\text { Deviation }\end{array}$ \\
\cline { 2 - 7 } & Statistic & Statistic & Statistic & $\begin{array}{c}\text { Statisti } \\
\text { C }\end{array}$ & $\begin{array}{c}\text { Std. } \\
\text { Error }\end{array}$ & Statistic \\
\hline Eksperimen 1 & 56 & 70 & 100 & 90.52 & .989 & 7.398 \\
\hline Eksperimen 2 & 55 & 40 & 100 & 79.82 & 2.082 & 15.438 \\
\hline Valid N (listwise) & 55 & & & & & \\
\hline
\end{tabular}

Dari tabel 1 menunjukan jumlah responden (N) berjumlah 111 siswa, dari 111 siswa ini nilai minimalnya pada eksperimen 1 berjumlah 70 dan pada eksperimen 2 berjumlah 40, nilai maximal pada eksperimen 1 berjumlah 100 dan pada eksperimen 2 berjumlah 100, rata-rata nilai dari Eksperimen 1 berjumlah 90.52 dengan Standar
Deviasi sebesar 7.398 dan rata-rata nilai dari Eksperimen 2 berjumlah 79.82 dengan Standar Deviasi sebesar 15.438. Nampak bahwa baik skor min, skor max dan skor rata-rata keterampilan komunikasi dari dua kelompok lebih tinggi kelompok eksperimen 1.

Tabel 2. Uji Mann Whitney

\begin{tabular}{|l|r|}
\hline \multicolumn{2}{|c|}{ Test Statistics } \\
\hline & $\begin{array}{c}\text { Keterampilan } \\
\text { Berkomunikasi }\end{array}$ \\
\hline Mann-Whitney U & 905.000 \\
\hline Wilcoxon W & 2445.000 \\
\hline Z & -3.802 \\
\hline Asymp. Sig. (2-tailed) & .000 \\
\hline a. Grouping Variable: Kelas \\
\hline
\end{tabular}

Tabel diatas menunjukan nilai $\mathrm{U}$ sebesar 905.000 dan Nilai W sebesar 2445.000. Apa bila dikonversikan ke nilai $\mathrm{Z}$ maka memiliki hasil 3.802. Nilai Sig atau $\mathrm{P}$ value sebesar $000<0,05$ dengan demikian terdapat perbedaan bermakna antara kedua kelompok yang berarti $\mathrm{H} 1$ diterima dan Ha ditolak.

Dari hasil presentasi yang sudah dilakukan, bahwa kelas yang diberi perlakuan dengan model pembelajaran Eksperimen 2 lebih besar rata- 
ratanya dibanding dengan kelas yang diberi perlakuan model pembelajaran Think Pair Share. Untuk mengetahui ada tidaknya perbedaan dalam keterampilan berkomunikasi antara eksperimen 1 dan eksperimen 2.

\section{PEMBAHASAN}

Berdasarkan hasil penelitian dan pengolahan data yang telah dilakukan untuk mengetahui keterampilan komunikasi siswa SD, diperoleh hasil bahwa model pembelajaran Numbered Head Together dapat meningkatkan keterampilan komunikasi lebih tinggi dibandingkan dengan model pembelajaran Think Pairs Share. Hasil uji hipotesis menggunakan teknik Mann Whitney seperti yang telah dilakukan terhadap keterampilan komunikasi yang terintegrasi dengan penugasan peta pikir kelompok eksperimen 1 dan eksperimen 2 diperoleh hasil signifikansi $000<$ 0,05, oleh karena dengan demikian terdapat perbedaan bermakna antara kedua kelompok yang berarti H1 diterima dan Ho ditolak. Artinya terdapat perbedaan keterampilan komunikasi yang signifikan pada kelas 5 SD Gugus Diponegoro 1, 3 dan 5 dalam pembelajaran yang menggunakan Numbered Head Together dan Think Pair Share.

Perbedaan perlakuan dimana hasil keterampilan komunikasi yang signifikan pada kelas 5 SD Gugus Diponegoro 1, 3 dan 5 pada kelas eksperimen 1 menggunakan model pembelajaran Numbered Head Together dan pada kelas eksperimen 2 menggunakan model pembelajaran Think Pair Share, didukung oleh rata-rata dari dua sampel dimana rata-rata keterampilan komunikasi pada eksperimen 1 sebesar 90.52 dan pada eksperimen 2 sebesar 79.82. Artinya bahwa eksperimen 1 dengan menggunakan model pembelajaran Numbered Head Together menunjukkan hasil keterampilan komunikasi lebih tinggi dari pada eksperimen 2 dengan menggunakan pembelajaran Think Pair Share.

Keampuhan model pembelajaran Numbered Head Together memberikan dampak lebih tinggi terhadap keterampilan berkomunikasi siswa SD, dibandingkan dengan menggunakan model pembelajaran Think Pair Share. Seperti teori yang dikemukakan oleh Aliputri, Sulasmono dan Setyaningsih $(2019 ; 25)$ bahwa Numbered Heads Together merupakan model pembelajaran yang dalam kegiatannya berisikan bahwa setiap siswa akan saling berbagi informasi, dan menjawab soal sesuai dengan nomor yang sudah dipanggil sehingga semua tim kelompok harus memahami dan mampu menyelesaikan pertanyaan yang diberikan oleh guru.

Hasil penelitian ini sejalan dengan penelitian yang dilakukan oleh kusnani (2011:108) bahwa keterampilan komunikasi siswa matematika peserta didik pada materi pokok segi empat menunjukan hasil bahwa model pembelajaran Numbered Heads Together lebih tinggi dibandingkan dengan pembelajaran dengan menggunakan model pembelajaran Think Pair Share. Mendukung penelitian dari kusnani (2011:108), Fauziah (2019:9) telah membuktikan juga bahwa pembelajaran dengan menggunakan model pembelajaran Numbered Head Together memiliki banyak pengaruh untuk meningkatkan keterampilan komunikasi siswa. Begitu pula penelitian yang telah dilakukan oleh Ismono (2019:272-273) bahwa model pembelajaran Numbered Head Together memiliki nilai rata-rata yang tinggi untuk meningkatkan keterampilan komunikasi siswa.

Rizkiana (2019:58) juga memperoleh hasil penelitian yang menunjukan bahwa pembelajaran menggunakan model pembelajaran Think Pairs Share memiliki keterampilan komunikasi yang tinggi dari pada komunikasi dengan menggunakan model pembelajaran konvensional. Penelitian yang juga bertentangan dengan penelitian ini adalah penelitian yang dilakukan oleh Rianingsih, Mawardi, Wardani (2019:344) yang menunjukkan bahwa pembelajaran dengan menggunakan model pembelajaran Think Pair Share dapat meningkatkan keterampilan komunikasi siswa SD. hasil penelitian ini juga berbeda dengan penelitian yang telah dilakukan oleh Daeka (2014: 89) memperoleh hasil bahwa pembelajaran dengan menggunakan model 
pembelajaran Numbered Head Together dan Think Pair Share sama efektifnya, dan kedua model pembelajaran tersebut lebih unggul dibandingkan dengan model konvensional.

Hasil penelitian ini dapat memperkuat hasil penelitian mengenai keampuhan model pembelajaran Numbered Head Together seperti penelitian yang telah dilakukan oleh Nanik Pratiwi dan Harun Nasrudin (2019;50-51) memperoleh hasil bahwa pembelajaran dengan menggunakan model pembelajaran Numbered Head Together dapat meningkatkan keterampilan komunikasi siswa. Lagur, Makur, dan Ramda (2018:365) hasil penelitian yang telah dilakukan bahwa pembelajaran dengan model pembelajaran Numbered Head Together terhadap kemampuan komunikasi memperoleh hasil yang tinggi. Keampuhan model pembelajaran Numbered Head Together terbukti bahwa dalam proses pembelajaran siswa menjadi siap semua, bersungguh-sungguh dalam berdiskusi dan pada peserta didik yang pandai akan berbagi ilmu untuk mengajarkan kepada peserta didik yang kurang pandai (Joko Susanto, 2012:73). Langkah-langkah yang dilakukan model pembelajaran Numbered Head Together yang pertama adalah penomoran, mengajukan pertanyaan, berpikir bersama dan menjawab pertanyaan. Kegiatan penomoran yang mampu yang mampu menghasilkan dampak pengiring terhadap siswa untuk belajar menerima anggota kelompok, pada sesi mengajukan pertanyaan siswa dituntut untuk bisa konsentrasi tinggi memperhatikan guru memanggil nomor dan membacakan pertanyaan. Siswa akan berdiskusi bersama dengan kelompoknya setelah itu berpikir untuk menemukan jawaban yang tepat bersama dengan kelompoknya. Setiap anggota kelompok memiliki tanggung jawab masing-masing yang harus ditanggung jawabkan, pada tahap pemberian jawaban siswa dengan percaya diri menuliskan jawabannya dipapan tulis dan semua temantemannya memperhatikan jawabannya yang dituliskan di papan tulis. Langkah terakhir yang dilakukan yaitu memberi penghargaan kepada siswa yang maju kedepan untuk bisa memotivasi siswa supaya lebih semangat dan rajin lagi. Dengan begitu pembelajaran dengan menggunakan model pembelajaran Numbered Head Together sangat terbukti sangat tinggi untuk meningkatkan keterampilan siswa dalam berkomunikasi.

\section{SIMPULAN}

Berdasarkan hasil penelitian tentang Efektivitas Model Pembelajaran Numbered Head Together dan Model Pembelajaran Think Pairs Share Ditinjau dari Keterampilan Komunikasi Siswa SD, maka penulis menarik kesimpulan bahwa berdasarkan hasil penelitian dan pengolahan data dengan menggunakan aplikasi SPSS, dapat diketahui bahwa uji mean pada grub statistik menunjukkan bahwa pada kelas eksperimen 1 dengan jumlah siswa $(\mathrm{N})$ sebanyak 56 siswa memiliki nilai rata-rata 90.52. Sedangkan pada kelas eksperimen 2 dengan jumlah siswa $(\mathrm{N})$ sebanyak 55 siswa memiliki rata-rata 79.82Hasil keterampilan komunikasi pada kelompok eksperimen 1 lebih tinggi diperkuat dengan hasil uji Mann Whitney. Berdasarkan uji Mann Whitney diperoleh hasil nilai U sebesar 905.000 dan Nilai $W$ sebesar 2445.000. Apa bila dikonversikan ke nilai Z maka memiliki hasil -3.800 . Nilai $\mathrm{Sig}$ atau $P$ value sebesar $000<0,05$ dengan demikian terdapat perbedaan bermakna antara kedua kelompok yang berarti $\mathrm{H}_{1}$ diterima. Artinya keterampilan komunikasi menggunakan model Numbered Head Together lebih tinggi secara signifikan dibandingkan dengan keterampilan komunikasi menggunakan model pembelajaran Think Pair Share.

\section{DAFTAR PUSTAKA}

Aliputri, Sulasmono, and Setyaningtyas. 2019. "Efektivitas Model Pembelajaran Kooperatif Tipe Think Pairs Share (TPS) Dan Numbered Head Together (NHT) Berbantuan CD Pembelajaran Terhadap Hasil Belajar Matematika." Jurnal Pendidikan Matematika 5 No 1 (1): 25.

Arifin, Zaenal. 2017. "Mengembangkan Instrumen Pengukur Critical Thinking Skills Siswa Pada Pembelajaran Matematika Abad 21." Jurnal Theorems 1 (2): 93. 
https://www.jurnal.unma.ac.id.

Daeka, Dalud. 2013. "Eksperimentasi Model Pembelajaran Kooperatif Tipe Numbered Head Together (Nht) Dan Think Pair Share (Tps) Ditinjau Dari Kreativitas Belajar Siswa Kelas Vii Smp Negeri Di Kabupaten Pacitan." Universitas Sebelas Maret.

Faisal, and Lova. 2019. Pembelajaran Tematik Di

Sekolah Dasar. Edited by Teguh Febri Sudarma. Medan - Indonesia: CV. HARAPAN CERDAS.

Fajrin, Oktavitastuti Awalia. 2019. "Pengaruh Pembelajaran Saintifik Think Pair Share (STPS) Terhadap Minat Belajar Siswa Kelas 5 SD." Jurnal Ilmiah Sekolah Dasar 3 No 1: 36-37.

Fauziah, Safira Hasna. 2019. "Implementasi Strategi Numbered Head Together (Nht) Berbasis Alat Peraga Dalam Pembelajaran Matematika Ditinjau Dari Komunikasi Matematik Siswa Kelas Vii Smp Negeri 3 Kartasura." Universitas Muhammadiyah Surakarta.

Hazilla, Dhesta. 2019. "Math Didactic: Jurnal Pendidikan Matematika Efektivitas Model Pembelajaran Kooperatif ... (C) by Author ( S )" 5 (1): 25.

Ismono. 2019. "Penerapan Model Pembelajaran Kooperatif Tipe Numbered Head Together (Nht) Untuk Melatihkan Keterampilan Komunikasi Siswa Kelas Xi Pada Materi Asam Basa Di Sma Negeri 1 Cerme." Unesa Journal of Chemical Education Vol. 8,No.

Khusnaini, Santi Nurul. 2011. "Keefektifitasan Pembelajaran Numbered Head Together Dan Pembelajaran Think Pair Share Terhadap Kemampuan Komunikasi Matematika Peserta Didik Pada Materi Pokok Segi Empat." Universitas Negeri Semarang.

L.R.Gay, Geoffrey E. Mills, and Peter Airasian. 2011. "Cloaking Malware with the Trusted Platform Module." Proceedings of the 20th USENIX Security Symposium.

Rianingsih, Dewi, Mawardi Mawardi, and Krisma Widi Wardani. 2019. "Penerapan Model Pembelajaran Tps (Think Pair Share) Dalam Rangka Meningkatkan Keterampilan Komunikasi Siswa Kelas 3." NATURALISTIC : Jurnal Kajian Penelitian Pendidikan Dan Pembelajaran 3 (2): 344. https://doi.org/10.35568/naturalistic.v3i2.39 4.

Rizkiana, Nadila, M. Coesamin, and Agung Putra WIjaya. 2019. "Efektivitas Model Pembelajaran Think Pair Share Ditinjau Dari Kemampuan Komunikasi Matematis Siswa." Jurnal Pendidikan Matematika Unila 7: 58.

Sari, Nova Hartika, Feriansyah Susunan, and I Dewa Putu Nyeneng. 2019. "Pengaruh Model Pembelajaran Think Pair Share Terhadap Hasil Belajar Fisika Siswa Ditinjau Dari Keterampilan Berkomunikasi." Jurnal Pendidikan Fisika VII 1: 69.

Siti Zubaidah. 2016. "Keterampilan Abad Ke-21: Keterampilan Yang Diajarkan Melalui Pembelajaran."Seminar Nasional $\begin{array}{llll}\text { Pendidikan } 2 \text { (2): } 4 . & \end{array}$ https://doi.org/10.1021/acs.langmuir.6b0284 2. 